\title{
Biosolid in the Chemical and Physical Attributes of a Typical Dystrophic Red Latosol
}

\author{
Kelly Dayana Benedet Maas ${ }^{1}$ (1) 0000-0002-7220-7698 \\ Oscarlina Lúcia dos Santos Weber ${ }^{2}$ (1) 0000-0002-0625-4904 \\ José Fernando Scaramuzza ${ }^{2}$ (1) 0000-0003-3920-7802 \\ Cristiane Ramos Vieira ${ }^{3}$ (D) 0000-0003-1936-1343
}

\begin{abstract}
This experiment assessed the effects of biosolids in the soil's chemical and physical characteristics. Soil was mixed to a biosolid in a totally randomized design, within a $5 \times 4$ factorial scheme: five doses of biosolid $(0,60,120,180$, and $\left.240 \mathrm{~m}^{3} \mathrm{ha}^{-1}\right)$ and four depths $(0-0.10 ; 0.10-0.20 ; 0.20-0.30 ; 0.30-0.40 \mathrm{~m})$. Soil was placed in $50 \mathrm{~L}$-tubs imitating the soil profile. Doses of biosolid were added to the soil and samples were retrieved after 120 days. Biosolid tended towards acidification, with very low $\mathrm{P}$ and $\mathrm{K}$ rates. Nutrient leaching, such as $\mathrm{Mg}$, increases microporosity and the reduction of soil macroporosity should be considered in high doses of biosolid.
\end{abstract}

Keywords: organic fertilization, chemical characteristics, physical characteristics, soil fertility.

\section{INTRODUCTION AND OBJECTIVES}

Population increase has caused great concern and challenges to public and private administrations with regard to the correct disposal of sewage sludge produced in sewerage treatment stations. The material has been treated until recently as an environment liability and discarded in landfills or open land without any follow-up or control. Inadequate disposal of biosolids causes contamination of soil and underground water, with great liabilities for public health and aquatic beings. However, the fact that these residues are rich in organic matter and in nutrients and may be employed as fertilizers and soil conditioners, increasing productivity is well-known. Several research works have been undertaken to prove these effects, especially with regard to the soil's chemical (Martins et al., 2015; Soares Filho et al., 2015), physical (Bonini et al., 2015), and biological (Andrade et al., 2016) characteristics, depending on the specific culture.

Organic matter in the soil provides greater structural quality (Schimiguel et al., 2014). Richness in organic matter may contribute towards the soil's structural quality due to stability of aggregates, which depends on the type of soil use and management. In fact, it is mainly affected by texture, mineralogy, quantity, and type of organic matter (Almeida et al., 2014). In other words, it provides greater production of dry matter by crops (Lourenzi et al., 2014).

Changes may occur after a few applications or may be detected after years of application, depending on soil type (Lourenzi et al., 2016). Consequently, results published in the literature have shown the influence or not of wastes in soil characteristics. After 13 annual successive applications of sewerage sludge, Andrade et al. (2014) did not detect rates of trace elements above those allowed by the Conama Resolution 420/2009 in eutrophic and dystrophic red latosol. Similarly, Nascimento et al. (2014) studied the effects of the application of sewerage sludge in Haplic Cambisol and Pereira et al. (2015) proved that sewerage sludge failed to interfere in the activity of soil microorganism. On the other hand, Pires et al. (2015) evidenced an increase in $\mathrm{N}$ rates after successive applications of sewage sludge. Vendruscolo et al. (2016) found that the chemical characteristics of degraded soil might be positively affected, in the long run, by sewage sludge, with an increase in

\footnotetext{
${ }^{1}$ Centro Universitário de Várzea Grande (Univag), Várzea Grande, MT, Brasil

${ }^{2}$ Universidade Federal de Mato Grosso (UFMT), Cuiabá, MT, Brasil

${ }^{3}$ Universidade de Cuiabá (Unic), Cuiabá, MT, Brasil
} 
$\mathrm{P}$ and $\mathrm{K}$ availability. The above was also reported by Lourenzi et al. (2016) when testing applications of organic compounds from shavings and liquid swine wastes which enhanced changes in $\mathrm{pH}$ and in $\mathrm{P}, \mathrm{K}, \mathrm{Cu}$, and $\mathrm{Zn}$ rates of red latosol.

Our analysis evaluates the influence of biosolids' chemical and physical attributes in a typical dystrophic red latosol (RLd).

\section{MATERIALS AND METHODS}

This experiment was performed in the greenhouse of the Faculdade de Agronomia e Zootecnia (FAAZ) of the Universidade Federal de Mato Grosso (UFMT) in Cuiabá, MT, Brazil, at $56^{\circ} 7^{\prime} \mathrm{W} ; 1^{\circ} 33^{\prime} \mathrm{S} ; 151.34 \mathrm{~m}$ altitude. Greenhouse was built of white shady material and covered with asbestos tiles, without temperature control. Soil was classified as typical dystrophic red latosol (RLd), clayey, as described by the Brazilian Soil Classification System (Embrapa, 2013) and collected on the campus of the Instituto Federal de Mato Grosso (IFMT), at depths $0-0.20 \mathrm{~m}$ and $0.20-0.40 \mathrm{~m}$. Samples were then retrieved for the soil's chemical and physical characterization (Table 1), following the Empresa Brasileira de Pesquisa Agropecuária (Embrapa) (1997).

Table 1. Chemical and physical characterization at different layers of a typical Dystrophic Red Latosol.

\begin{tabular}{|c|c|c|c|c|c|c|c|}
\hline Depth & pH & Al & $\mathrm{H}+\mathrm{Al}$ & $\mathrm{Ca}+\mathrm{Mg}$ & SB & TpH7.0 & true $t$ \\
\hline$(\mathrm{m})$ & $\mathrm{CaCl}_{2}$ & & $\mathrm{cmol}_{\mathrm{c}}$ & $\mathrm{dm}^{-3}$ & & & \\
\hline $0-0.20$ & 5.47 & 1.54 & 2.51 & 3.10 & 3.11 & 5.62 & 4.65 \\
\hline $0.20-0.40$ & 5.54 & 2.10 & 2.30 & 2.10 & 2.11 & 4.21 & 4.41 \\
\hline Depth & $\mathbf{P}$ & $\mathbf{K}$ & $\mathbf{V}$ & $\mathbf{m}$ & Clay & Silt & Sand \\
\hline$(\mathrm{m})$ & \multicolumn{2}{|c|}{$\mathrm{mg} \mathrm{dm^{-3 }}$} & \multicolumn{2}{|c|}{$\%$} & \multicolumn{3}{|c|}{$\mathrm{g} \mathrm{kg}^{-1}$} \\
\hline $0-0.20$ & 0.00 & 2.46 & 55 & 33 & 435 & 100 & 465 \\
\hline $0.20-0.40$ & 0.00 & 2.37 & 50 & 52 & 430 & 40 & 525 \\
\hline
\end{tabular}

Biosolid was collected at the compact model Sewage Treatment Station (ETE) from the Núcleo Habitacional Sucuri in Cuiabá, MT, Brazil. Residue came from the ascendant flux anaerobic digestion of sewerage of 245 homes, collected in liquid form and removed in $60 \mathrm{~L}$-barrels. Samples of residue were retrieved for chemical and physical characterization. Five simple samples were used to form compost that was then wrapped in a plastic flask and sent to the laboratory.

The experiment consisted of twenty cylindrical $50 \mathrm{~L}$ plastic barrels measuring $0.5 \mathrm{~m}$ height and $0.4 \mathrm{~m}$ diameter. Soil collected at a depth between 0 and $0.4 \mathrm{~m}$ was used for the organization of the barrels which were filled with soil at a depth $0.20-0.40 \mathrm{~m}$ (at the bottom), followed by soil collected at depth $0.0-0.20 \mathrm{~m}$ to simulate soil profile. Five doses of biosolid in liquid form were directly applied to the soil after filling the barrels. Two applications were done when the barrels were filled with soil and another was done after three months. Characteristics of the biosolid were determined by sampling following methodology by the Brazilian Ministry of Agriculture, Livestock and Supply (Mapa, 1988), given in Table 2.

Table 2. Chemical and physical characterization of biosolid according to analysis for applications 1 and 2 .

\begin{tabular}{|c|c|c|c|c|}
\hline Characteristic & Unit & $1^{\text {st }}$ application & $2^{\text {nd }}$ application & Total \\
\hline $\mathrm{pH}$ & & 7.3 & 7.3 & 14.6 \\
\hline Total N & \multirow{7}{*}{$\mathrm{g} \mathrm{L}^{-1}$} & 4.56 & 3.65 & 8.21 \\
\hline $\mathrm{N}\left(\mathrm{NH}_{4}\right)$ & & 0.62 & 0.44 & 1.06 \\
\hline $\mathrm{P}_{2} \mathrm{O}_{5}$ & & 0.81 & 0.69 & 1.50 \\
\hline $\mathrm{K}_{2} \mathrm{O}$ & & 0.039 & 0.33 & 0.36 \\
\hline $\mathrm{Ca}$ & & 0.31 & 0.28 & 0.59 \\
\hline S & & 0.12 & 0.083 & 0.20 \\
\hline $\mathrm{Zn}$ & & 9.48 & 2.88 & 12.36 \\
\hline $\mathrm{Cu}$ & \multirow{8}{*}{$\mathrm{mg} \mathrm{L}^{-1}$} & 2.88 & 2.75 & 5.63 \\
\hline $\mathrm{Fe}$ & & 205.98 & 204.73 & 410.71 \\
\hline $\mathrm{Mn}$ & & 2.47 & 1.54 & 4.01 \\
\hline B & & 4.18 & 3.74 & 7.92 \\
\hline $\mathrm{Ni}$ & & 0.21 & 0.18 & 0.39 \\
\hline $\mathrm{Pb}$ & & $<0.04$ & $<0.04$ & -- \\
\hline $\mathrm{Cr}$ & & $<0.15$ & $<0.15$ & -- \\
\hline $\mathrm{Cd}$ & & $<0.004$ & $<0.004$ & -- \\
\hline Density & $\mathrm{g} \mathrm{cm}^{-3}$ & 0.9670 & 0.8560 & 1.823 \\
\hline
\end{tabular}

A totally randomized design with a $5 \times 4$ factorial scheme comprised five doses of biosolid $(0,60,120,180$, and $\left.240 \mathrm{~m}^{3} \mathrm{ha}^{-1}\right)$, with assessment of soil characteristics at four depths $(0-0.10 ; 0.10-0.20 ; 0.20-0.30 ; 0.30-0.40 \mathrm{~m})$, with three replications. Applied doses corresponded to $0 \mathrm{~m}^{3} \mathrm{ha}^{-1}$ (0 L of biosolid per barrel); 60 (1.3 L); $120(2.5 \mathrm{~L}) ; 180$ (3.7 L); 240 (5.0 L). Irrigation was performed every two days during the experiment, with a $500 \mathrm{~mL}$ plastic beaker, during the dry period. When necessary, irrigation during the rainy period was performed at daily intervals greater or smaller than two days so that the field humidity could be maintained.

After 120 days, soil samples were collected at depths $0-0.10 ; 0.10-0.20 ; 0.20-0.30 ; 0.30-0.40 \mathrm{~m}$ for the chemical analyses and at depths $0-0.20$ and $0.20-0.40 \mathrm{~m}$ for the soil's physical analyses. Samples were then dried, loosed, and analyzed, following the methodology by Embrapa (1997), with the evaluation of the chemical characteristics $\mathrm{pH}$, $\mathrm{H}+\mathrm{Al}, \mathrm{Ca}, \mathrm{Mg}, \mathrm{K}, \mathrm{P}, \mathrm{SB}, \mathrm{TpH} 7,0$, effective $\mathrm{t}$ and V. Physical characteristics analyzed were macroporosity, microporosity, total porosity, density, and dispersed clay in water (DCW). Results underwent analysis of variance and regression, with SAS $^{\circledast}$ (Statistical Analysis System) 9.0. 


\section{RESULTS AND DISCUSSION}

\subsection{Changes in the soil's chemical attributes}

\subsection{1. $\mathrm{pH}$ and $H+A l$}

We found no difference for active acidity $(\mathrm{pH})$ and potential acidity $(\mathrm{H}+\mathrm{Al})$ rates of the soil at layers between 0 and $0.40 \mathrm{~m}$, with regard to doses of the biosolid (Figure 1).
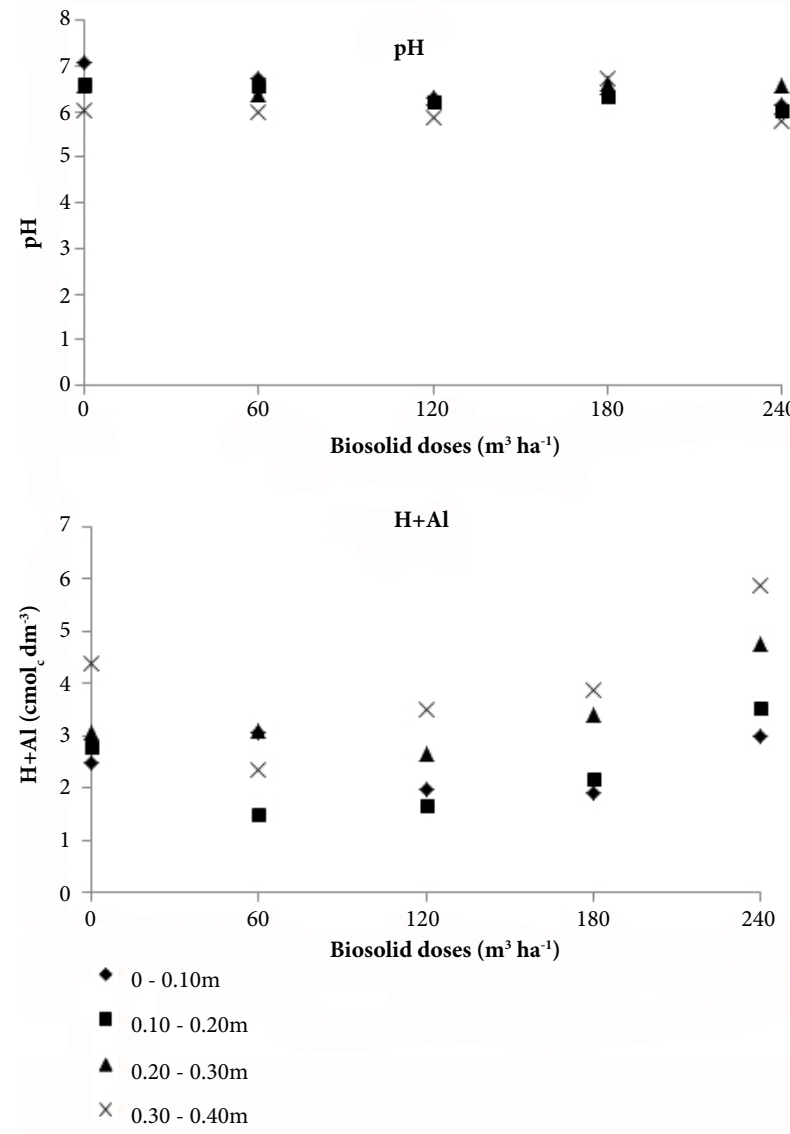

Figure 1. $\mathrm{pH}\left(\mathrm{H}_{2} \mathrm{O}\right)$ and $\mathrm{H}+\mathrm{Al}\left(\mathrm{cmol}_{\mathrm{c}} \mathrm{dm}^{-3}\right)$ of $\mathrm{RLd}$ after biosolid application.

Moreover, $\mathrm{pH}$ tended to decrease as dose and soil depth increased, also reported in the study by Santos et al. (2014) on the chemical characteristics of soil layers fertilized by sewage sludge. Since this may be due to the degradation of added organic matter by microorganisms, the biosolid as organic matter tends to acidify the soil. However, fertility was not reduced after two applications.

According to Antunes et al. (2015), nitrification of ammonia $\mathrm{N}$ increased the production of ions $\mathrm{H}^{+}$and decreased the soil's pH. Freitas et al. (2015) also registered acidification when applied organic cattle wastes to the soil. However, the authors insisted that the variable rates remained above the best scale for the plants, even with a slight $\mathrm{pH}$ reduction after the application of a higher dose of organic residue. In this case, all treatments were sufficient to neutralize all exchangeable $\mathrm{Al}$, also perceived in our assay.

According to classification by Sousa \& Lobato (2004), $\mathrm{pH}$ rates in $\mathrm{H}_{2} \mathrm{O}$ were classified between adequate and high, which may be due to $\mathrm{CO}_{3}$ and $\mathrm{HCO}_{3}$ rates, according to Nascimento et al. (2014). On the other hand, in the case of $\mathrm{H}+\mathrm{Al}$ rates, trend was an increase in soil depth and biosolid dose. Results are related to the acidifying trend of the residue and to increase in $\mathrm{H}^{+}$rate, as $\mathrm{pH}$ analysis revealed.

\subsection{2. $\mathrm{Ca}$ and $\mathrm{Mg}$}

Although there was no difference between Ca contents (Figure 2), an increase trend in doses 120 and $180 \mathrm{~m}^{3} \mathrm{ha}^{-1}$ was perceived at layers below $0.10 \mathrm{~m}$. Contents above $2.0 \mathrm{cmol} \mathrm{dm}^{-3}$ were reported only for dose $180 \mathrm{~m}^{3} \mathrm{ha}^{-1}$ at $0.30-0.40 \mathrm{~m}$ layer. Consequently, Ca contents varied between low and adequate (Sousa \& Lobato, 2004) which were expected due to low Ca content in the residue (Table 2). However, as a rule, the rates above are not adequate for layers used in the production of seedlings since they are insufficient to maintain growth. Consequently, according to use, $\mathrm{Ca}$ must be added to the residue.
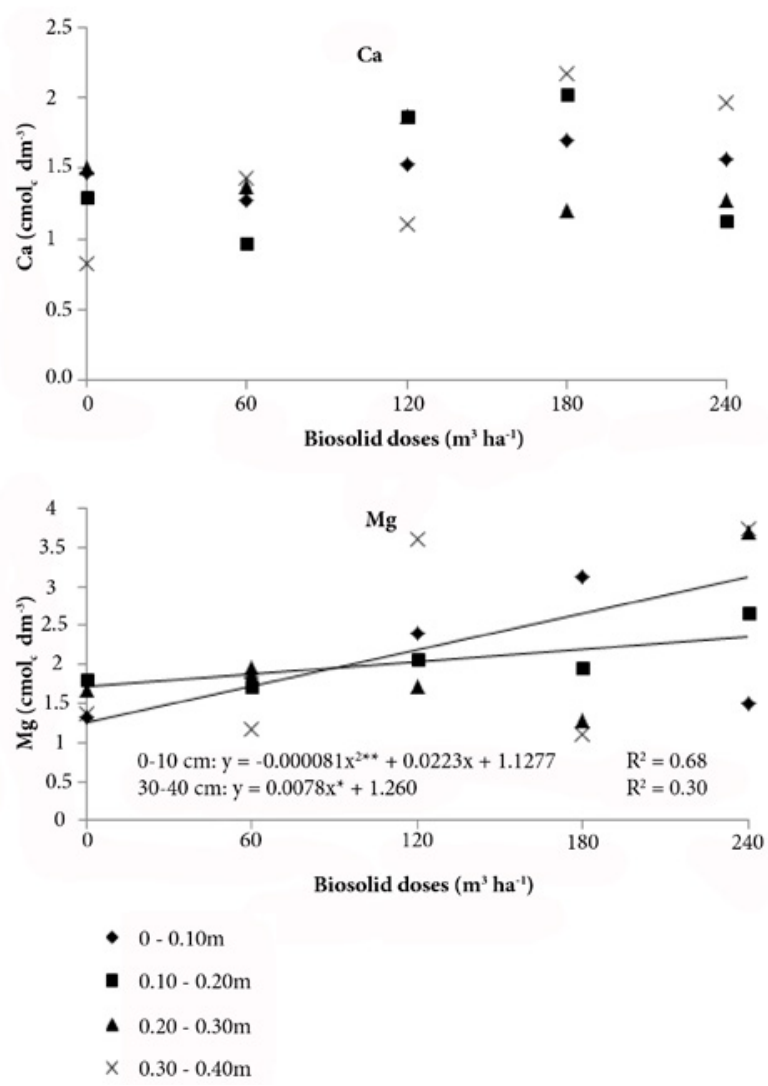

Figure 2. Ca and $\mathrm{Mg}$ contents, $\left(\mathrm{cmol}_{\mathrm{c}} \mathrm{dm}^{-3}\right)$ in $\mathrm{RLd}$ with biosolid application. 


\subsection{3. $P$ and $K$}

No difference occurred for P contents (Figure 3) between depth and doses applied. However, rates above $10 \mathrm{mg} \mathrm{dm}^{-3}$ were reported for the $0-0.10 \mathrm{~m}$ layer, with the application of $180 \mathrm{~m}^{3} \mathrm{ha}^{-1}$ of the biosolid. Since the soil in our experiment featured very low $\mathrm{P}$ contents, the results were due to the contents of the element in the biosolid.
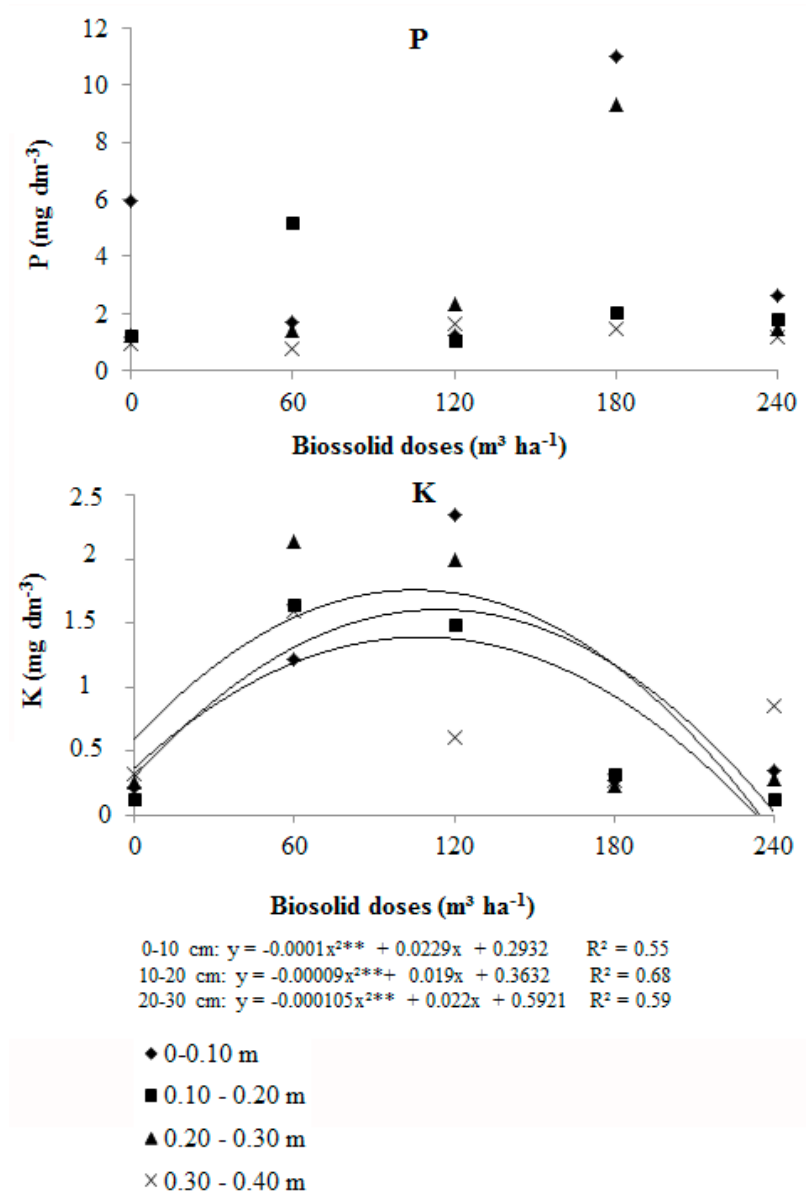

Figure 3. $\mathrm{P}$ and $\mathrm{K}\left(\mathrm{mg} \mathrm{dm}^{-3}\right)$ contents in RLd with biosolid application.

Maluf et al. (2015) insist results for P may be related to biological, such as microbial immobilization, and/or chemical processes, represented by $\mathrm{P}$ precipitation with ion forms, such as $\mathrm{Fe}, \mathrm{Al}$, and $\mathrm{Ca}$, and by specific adsorption.
Organically applied P, present in the biosolid composition, may show high resiliency due to the decomposition of the residue's organic matter and the consequent adsorption of the nutrient to the soil's mineral phase. Transition causes partial or total unavailability of $\mathrm{P}$ for plants (Vendruscolo et al., 2016). This has also been underlined by Martins et al. (2015) in their study on the effect of the application of sewage sludge in soil conditioning. According to these authors, a part of $\mathrm{P}$ in the sludge consists in the organic form, and increase in available $\mathrm{P}$ occurs, as a rule, a year after the application with mineralization.

K contents (Figure 3 ) increased according to the applied dose in depth, revealing the leaching of the element as shown in Mg. The highest available contents of K occurred in doses 120 and $180 \mathrm{~m}^{3} \mathrm{ha}^{-1}$, albeit low according to classification by Sousa \& Lobato (2004). In this case, K contents above $2 \mathrm{mg} \mathrm{dm}^{-3}$ were reported only at layer $0-0.10 \mathrm{~m}$ with dose $120 \mathrm{~m}^{3} \mathrm{ha}^{-1}$ and at layer $0.20-0.30 \mathrm{~m}$ with dose $60 \mathrm{~m}^{3} \mathrm{ha}^{-1}$.

Low $\mathrm{K}$ contents may be related to higher Mg contents since they are antagonistic elements. They may also be related to the element's content in the biosolid (Table 2). When the material is employed as substrate for seedling production, it has to be supplemented with a mineral K source.

\subsubsection{SB and $T p H 7.0$}

Average SB (Figure 4) increased up to dose $120 \mathrm{~m}^{3} \mathrm{ha}^{-1}$ at the $0-0.10 \mathrm{~m}$ layer, reaching $6.3 \mathrm{cmol}_{\mathrm{c}} \mathrm{dm}^{-3}$, with a later decrease at higher doses. Increase was linear at the 0.10$0.20 \mathrm{~m}$ layer, probably due to the leaching of $\mathrm{K}$ and $\mathrm{Mg}$ in the greatest doses of biosolid used when SB is obtained. Similar results have been reported for $\mathrm{TpH} 7.0$ (Figure 4), with the greatest average for dose $240 \mathrm{~m}^{3} \mathrm{ha}^{-1}$ at the $0.30-0.40 \mathrm{~m}$ layer, without any difference in the other layers. Stability was verified for results at dose $0 \mathrm{~m}^{3} \mathrm{ha}^{-1}$, with an increase at dose $120 \mathrm{~m}^{3} \mathrm{ha}^{-1}$ as from layer $0.20-0.30 \mathrm{~m}$ when dose $240 \mathrm{~m}^{3} \mathrm{ha}^{-1}$ was applied. In this case, TpH 7.0 is classified as low up to layer $0.20 \mathrm{~m}$ and adequate for layers lower than $0.20 \mathrm{~mm}$. These results were mainly affected by contents of $\mathrm{Mg}$ through leaching. Results were corroborated by Oliveira et al. (2016) when analyzed the disposal of solid wastes in Humaitá soils and water. 

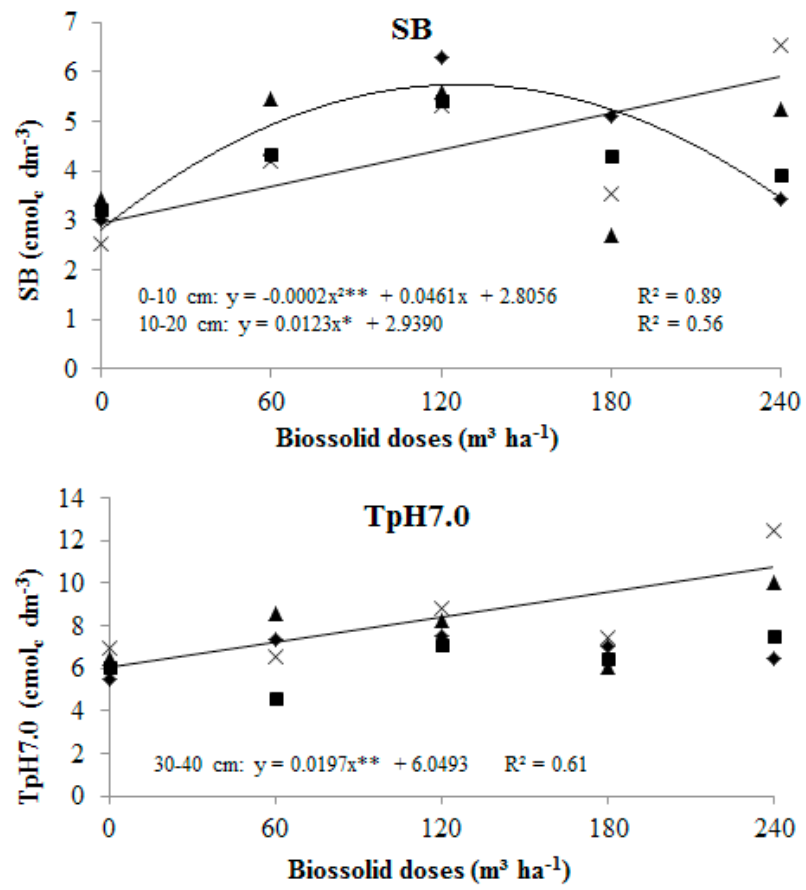

- 0-0.10 m

- $0.10-0.20 \mathrm{~m}$

^ $0.20-0.30 \mathrm{~m}$

$\times 0.30-0.40 \mathrm{~m}$

Figure 4. Sum of bases ( $\mathrm{SB}$, in $\mathrm{cmol}_{\mathrm{c}} \mathrm{dm}^{-3}$ ) and total cation exchange capacity (TpH 7.0, in $\mathrm{cmol}_{c} \mathrm{dm}^{-3}$ ) in RLd after application of biosolid.

\subsubsection{Effective t and $V \%$}

Effective $\mathrm{t}$ increased up to dose $120 \mathrm{~m}^{3} \mathrm{ha}^{-1}$ of biosolid due to $\mathrm{SB}$ rates. In fact, $\mathrm{Al}$ contents were zeroed in all treatments under analysis. Consequently, only the bases were considered when true $t$ was obtained (Figure 5), whereas, at layer $0.30-0.40 \mathrm{~cm}$, increase was linear with regard to biosolid doses due to leaching of bases at high doses of the residue.

Rates of effective $t$ remained lower than $3.0 \mathrm{cmol}_{c} \mathrm{dm}^{-3}$ only at dose $0 \mathrm{~m}^{3} \mathrm{ha}^{-1}$ at layer $0.30-0.40 \mathrm{~m}$ and at dose $180 \mathrm{~m}^{3} \mathrm{ha}^{-1}$ at $0.20-0.30 \mathrm{~m}$. Consequently, the highest rates for effective $t$ were reported at dose $240 \mathrm{~m}^{3} \mathrm{ha}^{-1}$ at layer 0.30-0.40 m, corroborating results for SB and CTC $\mathrm{pH} 7.0$ and related to $\mathrm{Ca}, \mathrm{Mg}$, and $\mathrm{K}$ contents in these conditions. Further, Nascimento et al. (2014) state - when one takes into account that SB and $\mathrm{V} \%$ are directly related to $\mathrm{Ca}, \mathrm{Mg}$, and $\mathrm{K}$ in the soil - one may note a greater addition content of $\mathrm{Ca}, \mathrm{Mg}$, and $\mathrm{K}$ in the treatment of limed sewage sludge provided higher $\mathrm{SB}$ and $\mathrm{V} \%$ rates.

V\% featured rates lower than $40 \%$ only at dose $0 \mathrm{~m}^{3} \mathrm{ha}^{-1}$ at layer $0.30-0.40 \mathrm{~m}$, where stability existed between rates up to layer $0.20-0.30 \mathrm{~m}$, with a later decrease. $\mathrm{V}$ rates increased with regard to depth for dose $60 \mathrm{~m}^{3} \mathrm{ha}^{-1}$, due to increase of SB and CTC. V decreased in depth when $120 \mathrm{~m}^{3} \mathrm{ha}^{-1}$ and $180 \mathrm{~m}^{3} \mathrm{ha}^{-1}$ were applied. However, at dose $240 \mathrm{~m}^{3} \mathrm{ha}^{-1}$ there was stability between $\mathrm{V}$ rates up to $0.30-0.40 \mathrm{~m}$ layer. The highest $\mathrm{V}$ rates were verified at layer $0.10-0.20 \mathrm{~m}$, at dose $120 \mathrm{~m}^{3} \mathrm{ha}^{-1}$. Results were obtained with adjustment of quadratic equations due to the variation in base rates because of an increase in the biosolid dose and consequent leaching throughout the soil profile.
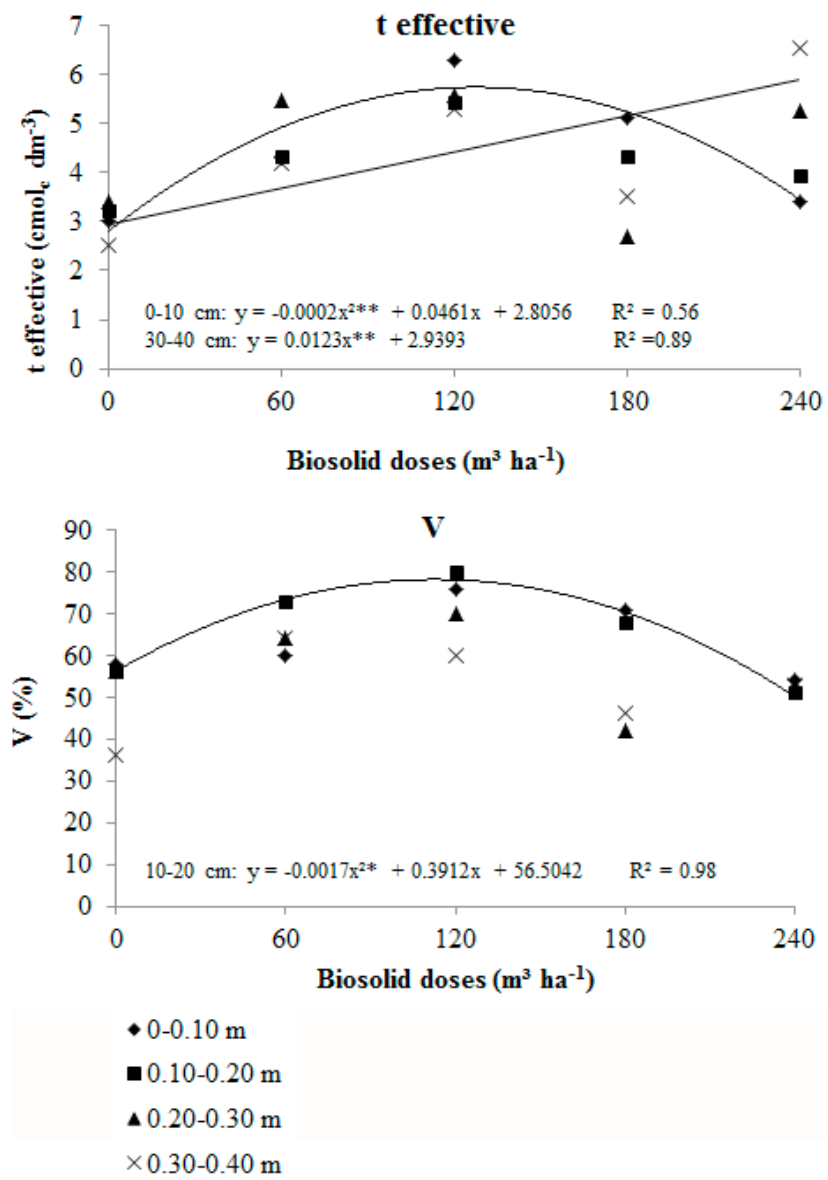

Figure 5. Effective cation exchange capacity (effective $t$, in $\mathrm{cmol}_{\mathrm{cm}}^{-3}$ ) and base saturation (V, in \%) in RLd with biosolid application.

\subsection{Alterations in the soil's physical attributes}

\subsubsection{Macroporosity and microporosity}

Although there was no difference in macroporosity (Figure 6) at layer $0-0.20 \mathrm{~m}$, a decreasing trend occurred as biosolid dose increased. A reduction occurred at layer $0.20-0.40 \mathrm{~m}$ up to dose $180 \mathrm{~m}^{3} \mathrm{ha}^{-1}$, with a later increase in the highest biosolid dose. In fact, the biosolid is an organic residue and 
may enhance effects similar to the soil's organic matter and increase in its porosity. Consequently, higher rates occurred at layer $0-0.20 \mathrm{~m}$ when compared to layer $0.20-0.40 \mathrm{~m}$. Further, Bonini et al. (2015) reported soil macroporosity was affected by the addition of sewage sludge due to an increase of a greater amount of organic matter to the soil.

Figure 6 shows increase in microporosity was due to depth and biosolid doses, since macroporosity decreased and the retention capacity in such conditions increased. According to Bonini et al. (2015), microporosity is only slightly affected by soil management. Whereas macroporosity is directly affected by the degradation of soil structure, only slight changes occur in microporosity.

Decrease in macroporosity and increase in microporosity show the soil's compacting capacity (Oliveira et al., 2015), due to the great volume of micropores which may be an advantage for water retention. However, losses in aeration and gas circulation occur, characterizing compacting and loss of the soil's physical quality (Rossetti \& Centurion, 2013), with negative effects in plant growth.
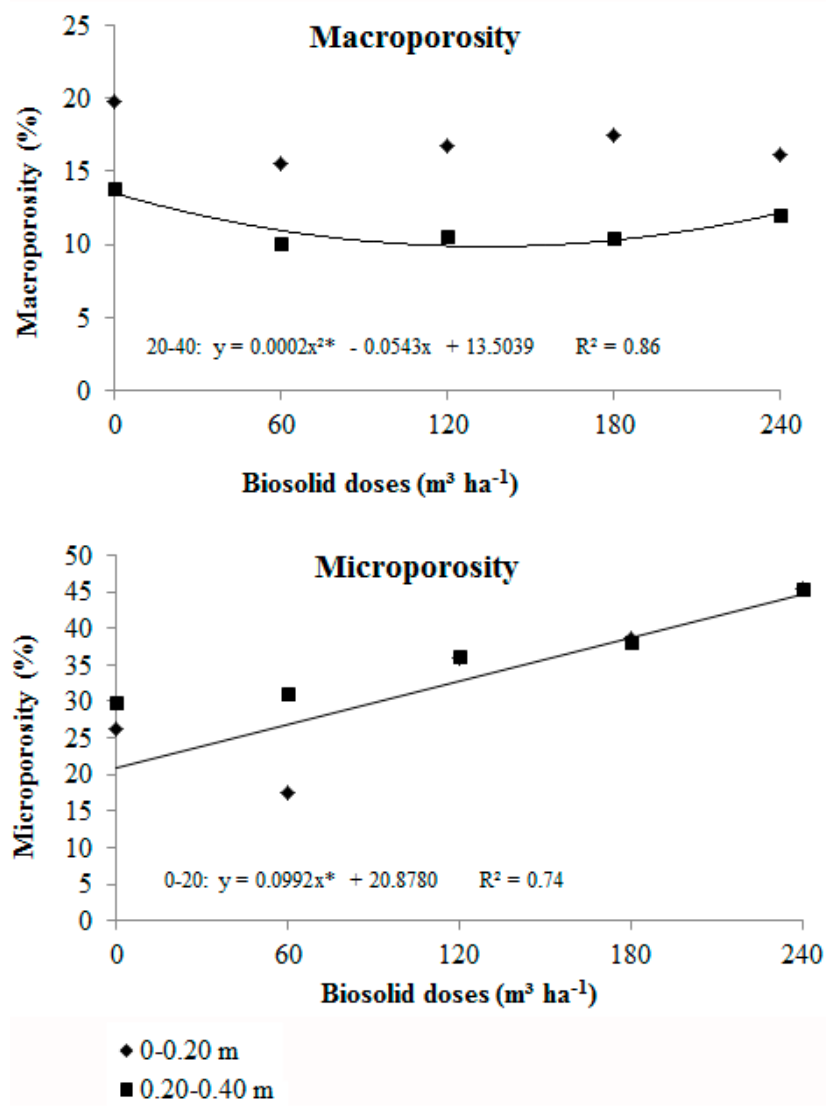

Figure 6. Macroporosity and microporosity (\%) in RLd with biosolid application.
Thus, to observe the effects of biosolid applications to the soil throughout the period is greatly relevant. Depending on the applied dose, it may cause the emergence of compacted layers below $0.20 \mathrm{~m}$.

\subsubsection{Porosity and density}

The highest total porosity rate (Figure 7) has been reported at doses 180 and $240 \mathrm{~m}^{3} \mathrm{ha}^{-1}$, whilst the lowest lay at $60 \mathrm{~m}^{3} \mathrm{ha}^{-1}$, at layer $0-0.20 \mathrm{~m}$, with adjustment of linear equation at this layer. There was a decrease between layers, with an increasing trend according to biosolid doses.
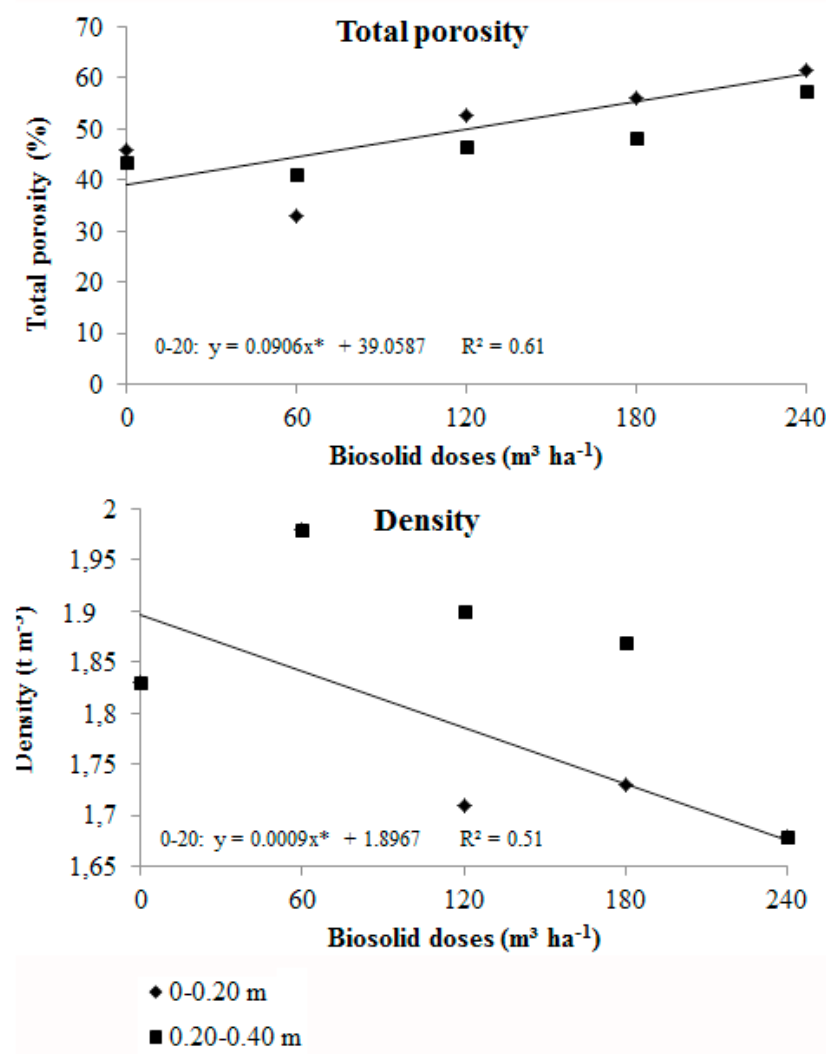

Figure 7. Total porosity (\%) and density $\left(\mathrm{t} \mathrm{m}^{-3}\right)$ in RLd with application of biosolids.

Total porosity is an important index for the soils' physical quality. In fact, a greater volume of pores reveals conditions where soil did not undergo deep alterations due to movement and churning pressure (Oliveira et al., 2015). Considering the depths analyzed, similarity between rates indicates the effects of the biosolid were the same at depth $0.40 \mathrm{~m}$. Since there was no sheer reduction of porosity, 
applications did not affect soil compacting and successive application should be attempted.

We found no sheer changes in density (Figure 7) between layers $0-0.20 \mathrm{~m}$ and $0.20-0.40 \mathrm{~m}$. It is thus possible to adjust linear equation for this feature at the surface layer $(0-0.20 \mathrm{~m})$. Whereas a greater density was reported at dose $60 \mathrm{~m}^{3} \mathrm{ha}^{-1}$, reduction occurred in higher doses, perhaps related to a smaller porosity in the treatment. According to Stone et al. (2002), an increase in soil density is due to the reduction of total porosity and macroporosity, without any changes in microporosity.

\subsection{Dispersed clay in water (DCW)}

Adjustment of the regression equation to DCW rates was impossible (Figure 8) in the case of depth and in the case of doses of the biosolid applied. However, there was a decrease trend when the biosolid dose increased, due to the activity of the residue that acts as an organic matter and increases the soil's microporosity. DCW rates at deeper layers were similar to those at the surface, indicating a translocation of material, especially at dose $240 \mathrm{~m}^{3} \mathrm{ha}^{-1}$, in which there was an $81 \%$ DCW reduction between layers $0-0.20 \mathrm{~m}$ and $0.20-0.40 \mathrm{~m}$.

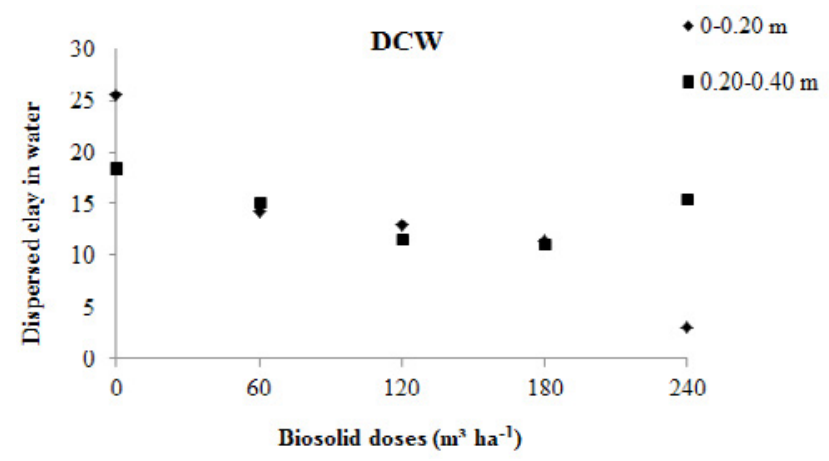

Figure 8. Dispersed clay in water (DCW) in RLd with application of biosolids.

In fact, biosolid triggered decrease of DCW through an increase of applied doses that, in turn, may directly affect the soil's compact capacity. According to Santiago et al. (2018), increase in MOS provided a better soil structure, a decrease in DCW, and an increase of flocculation degree.

Several soil physical variables may be changed by the dispersion of clay, such as decrease in infiltration and permeability rates due to the obstruction of pores within the surface layer. Consequently, application of biosolid may be an alternative to increase particle structuring and reducing clay dispersion.

\section{CONCLUSIONS}

Since biosolids revealed an acidifying trend, further studies on the theme should be undertaken with more than two application of the residue.

$\mathrm{K}$ and $\mathrm{P}$ contents in the biosolid may be very low and should be supplemented with the elements prior to their employment in seedling production.

High doses of biosolid enhance Mg leaching and increase microporosity.

Biosolid affected the soil's physical characteristics and increased the substrate's retention capacity. It may also form layers with high density throughout the soil's profile Further studies should be undertaken to verify the effects of the application over the years.

\section{SUBMISSION STATUS}

Received: 28 June 2018

Accepted: 24 Nov. 2018

Associate editor: Marcos Gervásio Pereira

(D) 0000-0002-1402-3612

\section{CORRESPONDENCE TO \\ Cristiane Ramos Vieira}

Universidade de Cuiabá (Unic Beira Rio I), Rua Manoel José de Arruda, 3.100, Jardim Europa, CEP 78065-900, Cuiabá, MT, Brasil e-mail: cris00986@hotmail.com

\section{REFERENCES}

Almeida RF, Machado HÁ, Martins FP, Queiroz IDS, Teixeira WG, Mikhael JER, Borges EN. Correlação do tamanho e distribuição dos agregados em Latossolos Amarelo da região do triângulo mineiro em diferentes ambientes. Bioscience Journal 2014; 30(5): 1325-1334.

Andrade MG, Lima AST, Melo WJ, Santos EJ, Herrmann AB. Elementos-traço em dois latossolos após aplicações anuais de lodo de esgoto por treze anos. Semina: Ciências Agrárias 2014; 35(1): 135-148. 10.5433/1679-0359.2014v35n1p135

Andrade LC, Andreazza R, Camargo FAO. Atividade microbiana em solos sob doses de lodo de estação de tratamento de efluentes de um aterro industrial. Ciência Rural 2016; 46(2): 267-272. 10.1590/0103$8478 \mathrm{cr} 20140871$

Antunes RM, Castilhos RMV, Castilho DD, Leal AO, Andreazza R. Crescimento inicial de acácia-negra com vermicompostos de diferentes resíduos agroindustriais. Ciência Florestal 2015; 26(1): 1-9. 10.5902/1980509821060

Bonini CSB, Alves MC, Montanari R. Recuperação da estrutura de um latossolo vermelho degradado utilizando lodo de esgoto. Revista Brasileira de Ciências Agrárias 2015; 10(1): 34-42. 10.5039/ agraria.v10i1a4513 
Empresa Brasileira de Pesquisa Agropecuária - Embrapa. Centro Nacional de Pesquisa de Solos. Sistema brasileiro de classificação de solos. 3rd ed. Brasília: Embrapa; 2013.

Empresa Brasileira de Pesquisa Agropecuária - Embrapa. Centro Nacional de Pesquisa de Solos. Manual de métodos de análise de solos. 2nd ed. Rio de Janeiro: Embrapa; 1997.

Freitas GA, Chagas JFR, Melo MP, Negreiro Neto JV, Leite RC, Silva RR. Resíduo orgânico bovino enriquecido com fontes de cálcio como corretivo da acidez do solo. Global Science and Technology 2015; 8(3): 1-11.

Lourenzi CR, Ceretta CA, Brunetto G, Girotto E, Tiecher TL, Vieira RCB et al. Pig slurry and nutrient accumulation and dry matter and grain yield in various crops. Revista Brasileira de Ciência do Solo 2014; 38(3): 949958. 10.1590/S0100-06832014000300027

Lourenzi CR, Scherer EE, Ceretta CA, Tiecher TL, Cancian A, Ferreira PAA, Brunetto G. Atributos químicos de latossolo após sucessivas aplicações de composto orgânico de dejeto líquido de suínos. Pesquisa Agropecuária Brasileira 2016; 51(3): 233-242. 10.1590/S0100-204X2016000300005

Maluf HJG, Soares BEM, Silva IR, Neves JCL, Silva MFO. Disponibilidade e recuperação de nutrientes de resíduos culturais em solo com diferentes texturas. Revista Brasileira de Ciência do Solo 2015; 39(6): 1690-1702. 10.1590/01000683rbcs20140658

Ministério da Agricultura, Pecuária e Abastecimento - Mapa. Laboratório Nacional de Referência Vegetal. Análise de corretivos, fertilizantes e inoculantes: métodos oficiais. Brasília: Lanarv; 1988.

Martins DR, Camargo AO, Melo LCA, Ribeirinho VS, Andrade CA. Estado nutricional de cafeeiros comerciais após aplicações de lodo de esgoto como condicionador do solo. Revista Ciências Agrárias 2015; 58(3): 248-256. 10.4322/rca.2019

Nascimento AL, Sampaio RA, Zuba Junio GR, Fernandes LA, Cruz SF, Carneiro JP, Barbosa CF et al. Atributos químicos do solo adubado com lodo de esgoto estabilizado por diferentes processos e cultivado com girassol. Bioscience Journal 2014; 30(1): 146-153.

Oliveira DMS, Lima RP, Verburg EEJ. Qualidade física do solo sob diferentes sistemas de manejo e aplicação de dejeto líquido suíno. Revista Brasileira de Engenharia Agrícola e Ambiental 2015; 19(3): 280-285. 10.1590/1807-1929/agriambi.v19n3p280-285

Oliveira BOS, Tucci CAF, Neves AF Jr, Santos AA. Avaliação dos solos e das águas nas áreas de influência de disposição de resíduos sólidos urbanos de Humaitá, Amazonas. Engenharia Sanitária e Ambiental 2016; 21(3): 593-601. 10.1590/S1413-41522016133274
Pereira NGF, Frazão LA, Oliveira ALG, Cardoso PHS, Sampaio RA, Fernandes LA. Efeitos da aplicação de lodo de esgoto estabilizado por diferentes processos nos atributos químicos e microbiológicos de um cambissolo háplico. Cadernos de Ciência e Tecnologia 2015; 32(1-2): 115-127. 10.35977/0104-1096.cct2015.v32.23307

Pires AMM, Andrade CA, Souza NAP, Carmo JB, Coscione AR, Carvalho CS. Disponibilidade e mineralização do nitrogênio após aplicações sucessivas de lodo de esgoto no solo, estimadas por meio de incubação anaeróbica. Pesquisa Agropecuária Brasileira, Brasília 2015; 50(4): 333-342. 10.1590/S0100-204X2015000400009

Rossetti KV, Centurion JF. Sistemas de manejo e atributos físicohídricos de um Latossolo Vermelho cultivado com milho. Revista Brasileira de Engenharia Agrícola e Ambiental, Campina Grande 2013; 17(5): 472-479. 10.1590/S1415-43662013000500002

Santiago FS, Montenegro SMGL, Pinheiro MRA. Índice de qualidade do solo em cultivo agroecológico e convencional no semiárido potiguar, Brasil. Revista Verde de Agroecologia e Desenvolvimento Sustentável 2018; 13(1): 97-105. 10.18378/rvads. v13i1.5333

Santos FEV, Kunz SH, Caldeira MVW, Azevedo CHS, Rangel OJP. Características químicas de substratos formulados com lodo de esgoto para produção de mudas florestais. Revista Brasileira de Engenharia Agrícola e Ambiental 2014; 18(9): 971-979. 10.1590/18071929/agriambi.v18n09p971-979

Schimiguel R, Sá JCM, Briedis C, Hartman DC, Zuffo J. Estabilidade de agregados do solo devido a sistemas de cultivo. Synergismus scyentifica UTFPR 2014; 9(1).

Soares Filho CV, Heinrichs R, Perri SHV, Correia AC. Atributos químicos no solo e produção de Cynodon dactylon cv. Tierra verde sob doses de biofertilizante orgânico. Revista Brasileira de Saúde e Produção Animal 2015; 16(1): 23-35. 10.1590/S151999402015000100003

Souza DMG, Lobato E. Cerrado: correção do solo e adubação. Planaltina: Embrapa Cerrados; 2004.

Stone LF, Guimarães CM, Moreira JAA. Compactação do solo na cultura do feijoeiro. I: efeitos nas propriedades físico-hídricas do solo. Revista Brasileira de Engenharia Agrícola e Ambiental 2002; 6(2): 207-212. 10.1590/S1415-43662002000200005

Vendruscolo EP, Leal AJF, Alves MC, Souza EJ, Souto Filho SN. Atributos químicos de solo degradado em função da adoção de biochar, culturas de cobertura e residual da aplicação de lodo de esgoto. Revista Ciências Agrárias 2016; 59(3): 235-242. 10.4322/ rca.2161 